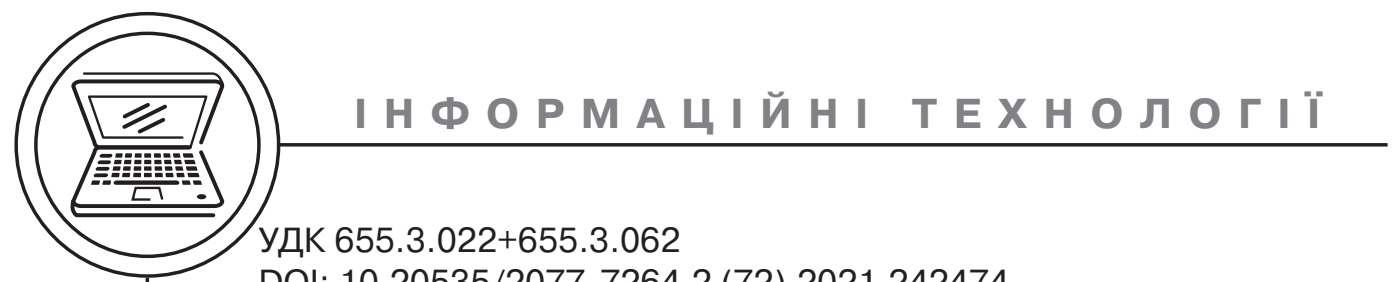

DOI: $10.20535 / 2077-7264.2$ (72).2021.242474

() Є. В. Штефан, д-р техн. наук, проф., Т. А. Роїк, д-р техн. наук, проф., О. В. Зоренко, канд. техн. наук, доц., О. П. Шостачук, старш. викл., КПІ ім. Ігоря Сікорського, Київ, Україна

\title{
МЕТОДИ ЦИФРОВОГО УПРАВЛІННЯ ПОЛІГРАФІЧНИМИ ПРОЦЕСАМИ
}

\section{Робота присвячена проблемі методологічного забезпечення цифрового керування та комп'ютерних методів інформа- ційного управління технологічними процесами при реалізації виробничих режимів у логістичній системі «макет-виріб». \\ Розглянуто особливості створення спеціалізованих ін- формаційних систем у виді програмно-технічних засобів для керування технологічними показниками в умовах їх реальної залежності від властивостей вхідних мате- ріалів, стану, налагодження та режиму основних елементів обладнання.}

Ключові слова: об'єктно-орієнтована методика; інформаційна система; цифрова та математична моделі; інтелектуальна експертна система; проблемно-орієнтовані засоби; поліграфічне виробництво.

\section{Постановка проблеми}

Однією з основних рис сучасного поліграфічного виробництва $€$ інтенсивне впровадження цифрового керування та комп'ютерних методів інформаційного управління технологічними процесами при реалізації виробничих режимів у логістичній системі «макет-виріб». Це обумовлює поступове реформування управління технологічними процесами в поліграфічній галузі, що в поточний період прямує від аналогового до інформаційного [1]. Системне збільшення інформаційних потоків у поліграфічному виробництві створює проблеми, пов'язані з ефективним управлінням технологічними процесами виготовлення поліграфічної продукції, яке необхідно реалізувати у реальному часовому вимірюванні. Крім того, через використання новітнього поліграфічного обладнання, постійне удосконалення технологічних процесів та розширення асортиментів сучасних витратних матеріалів, в першу чергу таких, як папір, фарба, клейові полімерні композиції, виникає необхідність у впровадженні засобів комплексної автоматизації управління, налаштування та контролю технологічних і апаратних параметрів виробництва.

() Автор(и) 2021. Видавець КПІ ім. Ігоря Сікорського.

CC BY 4.0 (https://creativecommons.org/licenses/by/4.0/). 
Для цього необхідно визначати певний набір технологічних показників та їх кількісний вплив на показники якості відбитків, наприклад, для друкарських процесів, для яких це будуть параметри переміщення аркушів або полотна паперу, параметри подачі фарби та зволожувальних розчинів, параметри суміщення фарб та кольоровідтворення тощо. Таким чином, виникає проблема у створенні спеціалізованих інформаційних систем (IC) у виді програмно-технічних засобів для керування відповідними технологічними показниками в умовах їх реальної залежності від властивостей вхідних матеріалів, станом, налаштуванням та режимами основних елементів обладнання. Залежно від проблемної орієнтації і складності самого технічного об'єкту IC може складатися (на основі принципу об'єктної декомпозиції) з певного набору підсистем, які у формі людино-машинної системи забезпечать автоматизований збір інформації з вимірювальних перетворювачів сигналів або з бази відповідних критеріальних параметрів і первинне оброблення (фільтрування сигналів, лінеаризація характеристик перетворювачів, «офізичування» сигналів - перетворення та візуалізації сигналів у значення параметрів у фізичних одиницях вимірювання) для розрахунку, видачі та реалізації керуючих впливів на елементи технологічного обладнання відповідно до прийнятих критеріїв управління [2].

\section{Аналіз попередніх досліджень}

На сучасних поліграфічних підприємствах вже досить широко використовуються IC [3, 4]. В роботі [5] представлено варіант IC Workflow, яка реалізує управління всього бізнес-процесу поліграфічного виробництва з використанням концепцій CALS (Continuous Acquisition and Life cycle Support - концепція та ідеологія інформаційної підтримки життєвого циклу продукції на всіх його стадіях, заснована на використанні єдиного інформаційного простору), що забезпечує одноманітні способи взаємодії всіх учасників цього циклу: замовників продукції (включаючи державні установи і відомства), постачальників (виробників) продукції, експлуатаційного і ремонтного персоналу. У даному випадку можна казати про реалізацію функціональної моделі поліграфічного підприємства (ФМПП). Проведення декомпозиції ФМПП приводить до проблемно-орієнтованих методів побудови IC. Недоліком подібного типу IC є відсутність підсистем, які реалізують алгоритми прийняття рішень з управління параметрів експлуатації певних модулів технологічного обладнання. Для цього доцільно розглядати геометричну модель поліграфічного підприємства. Виконання декомпозиції відповідної геометричної моделі є базовим принципом об'єктноорієнтованих методів розроблення IC [6].

Таким чином, в основі розроблення сучасних IC різного технічного призначення покладено умовне розділення моделі виробничого процесу на функціональну та геометричну моделі [7]. Залежно від можливих варіантів геометричних моделей (адміністративні та виробничі 
ділянки, технологічні процеси та обладнання, програмне-технічне забезпечення тощо) запропоновано методи об'єктно-орієнтованого моделювання та об'єктно-орієнтованого програмування, а також об'єктно-орієнтованих обчислювальних методів у межах відповідної проблемної орієнтації [8]. Тобто, об'єктно-орієнтовані методології (ООМ) науковопізнавальної та творчої діяльності відображають природні зв'язки та відношення між предметами та явищами у той мірі, в якої вони визначені дослідником в контексті проблеми, що підлягає розв'язанню. Один з базових принципів ООМ - «інкапсуляція» (об'єднання функцій перетворення параметрів у межах єдиної структури та приховування її стану від інших зовнішніх структур) знайшов своє застосування при модельному відображенню друкарського процесу у формі «чорної скриньки» [9]. Крім того, ООМ з побудови інформаційних систем цифрового визначення та стабілізації параметрів технологічних процесів у рулонних друкарських машинах знайшов своє відображення у низці робіт, де розглянуті різні аспекти проблемної орієнтації [10] (тобто у конкретизованих геометричних моделях).

Таким чином, застосування об'єктно-орієнтованих методів розроблення інформаційних систем для ефективного супроводження функціонування об'єктів поліграфічної галузі дозволяє розв'язувати актуальні проблеми інтеграції інформації про властивості об'єкта (геометричної, атрибутивної, конструктивної, топологічної, графічної тощо) з його функціональними параметрами.

\section{Мета роботи}

Визначення можливості використання об'єктно-орієнтованих методів при створенні інформаційних проблемно-орієнтованих систем контролю та управління процесами відтворення відбитків з врахуванням взаємовпливу конструктивно-технологічних параметрів процесів та обладнання поліграфічних виробництв.

\section{Результати проведених досліджень}

Відповідно [9] вважаємо, що IC конкретної технології друку це $\epsilon$ сукупність методів, засобів і прийомів, що використовуються для пошуку, нагромадження, опрацювання, зберігання, подання, передавання інформації та виготовлення поліграфічних виробів за допомогою засобів обчислювальної техніки і зв'язку. На основі цього пропонуються основні принципи створення IC для аналізу наукових проблем у предметній області процесів та обладнання поліграфічних виробництв.

Приймаємо об'єкт досліджень у виді мультикомпонентної системи взаємозв'язаних об'єктів задруковувані матеріали та засоби їх подавання, фарби, друкарські форми, ракельні механізми, пристрої та режими термомеханічного навантаження тощо. Теоретичні аспекти даної предметної області базуються на узагальнених емпіричних залежностях, що є результатом оброблення експериментальних даних або на математичних залежностях у формі нелінійних просторово-нестаціонарних крайових задачах математичної фізики, що описують закономірності по- 
ведінки відповідних об'єктів досліджень. Завдяки появі ЕОМ великої потужності з'явилася можливість ефективного розв'язання нелінійних просторово-нестаціонарних крайових задач математичної фізики та отримання відповідних кількісних характеристик, які відображають поведінку об'єктів, що розглядаються, у різноманітних технологічних операціях поліграфічних виробництв. При цьому джерелом інформації про поведінку ОД у межах обраної науково-технічної проблеми доцільно використовувати результати обчислень (обчислювальний експеримент), головним принципом проведення якого є: розгляд у єдиному комплексі постановки задачі, методів її розв'язування та реалізації розрахункового алгоритму у виді програмної системи (цифрової моделі).
Таким чином, можна запропонувати тип IC контролю та управління процесом друку: «цифрова модель-інтелектуальна експертна система-система автоматизованого управління» (рис. 1).

Залежно від обраної проблемної орієнтації предметна область має наступне наповнення: закономірності взаємодії друкувальний елемент-відбиток, ракельдрукарська форма, робочі органи-задруковуваний матеріал тощо; розподілення тиску по робочим поверхням; характеристики задруковуваного матеріалу, фарби та зволожувальних розчинів; параметри процесів сушіння шару фарби та суміщення фарб у друкарських машинах; конструктивно-технологічні параметри механізмів та показники їх надійності, параметри бокового зміщення

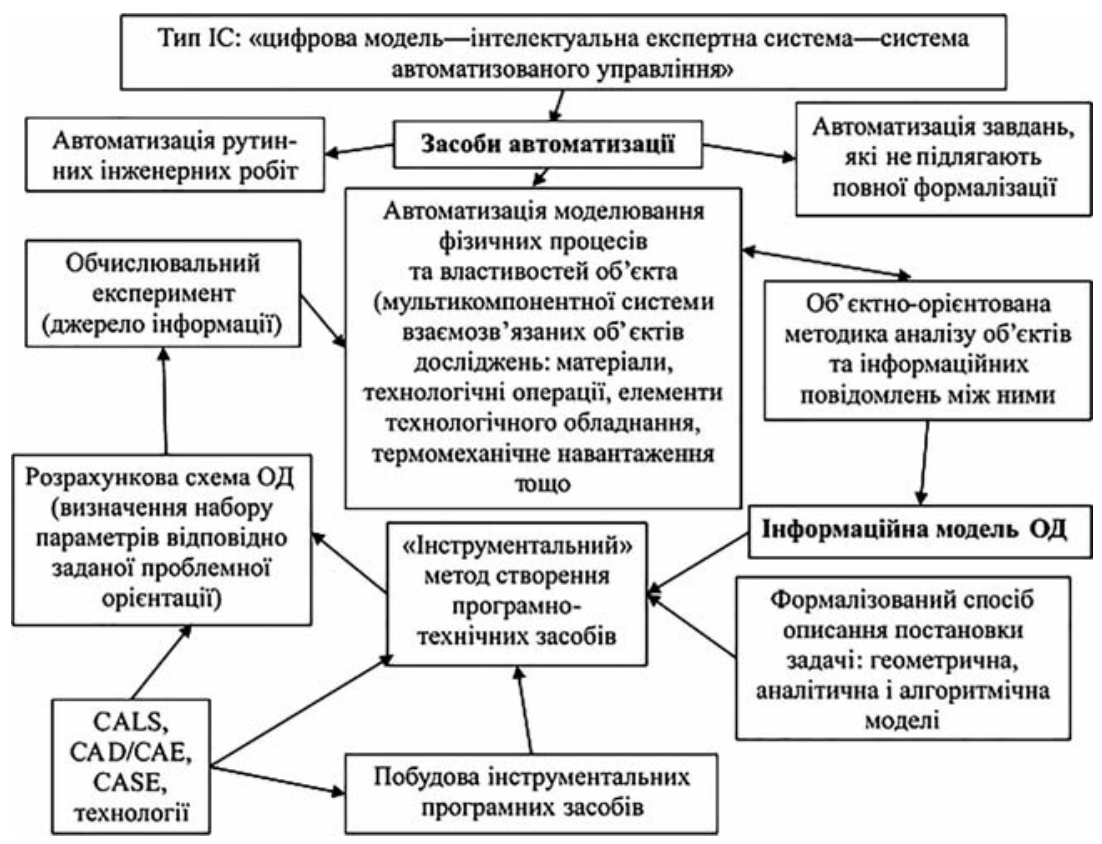

Рис. 1. Схема розроблення інформаційних систем 
задруковуваного полотна паперу; показники якості виробів тощо.

Згідно наведеної методики (рис. 1), одним з основних елементів запропонованого варіанту IC $€$ інформаційна модель об'єкту досліджень (ІМ ОД). Враховуючі, що друкарський процес, як правило, є складним об'єктом - відкритою трибодинамічною системою [11], доцільно використовувати ООМ побудови інформаційної моделі відповідних ОД, яка складається 3 наступних основних етапів:

- декомпозиція предметної області на окремі елементи;

- аналіз сукупності атрибутів (властивостей) елементів;

- об'єднання елементів у класи;

- аналіз інформаційних повідомлень між елементами.

Таким чином, використання ООМ дозволяє ефективно провести декомпозицію технічної системи на підсистеми, класифікувати їх і описати у виді скінченої сукупності класів та зв'язків з подальшою формалізацією інформації про ОД. При такому підході ІМ ОД складається з наступних основних елементів [6, 8]:

- графічне представлення IM, виконане у визначеній нотації (діаграму «сутність-зв'язок»);

- описання підсистем і атрибутів, що містить списки всіх підсистем і атрибутів моделі та забезпечує організовану сукупність описів підсистем, атрибутів і доменів;

- описання зв'язків між елементами технічної системи.

У цій роботі розглядається один 3 можливих варіантів IC, який відповідає прийнятому напряму проблемної орієнтації - контроль та управління технологічними параметрами процесів виготовлення поліграфічної продукції (рис. 2).

При розгляданні конкретних прикладів у межах запропонованої IC розроблена загальна методика визначення взаємозв'язку конструктивно-технологічних параметрів технічних систем (рис. 3). Ця методика дозволяє створити основу для автоматизованого аналізу необхідних параметрів та властивостей технічних систем поліграфічних виробництв.

Згідно запропонованої концепції розроблення IC основним призначенням інформаційної моделі об'єкта досліджень є розроблення його (або його складових частин) розрахункової схеми (РС). Тобто, метод створення PC заснований на синтезі всієї інформації з врахуванням основних напрямів дослідження ОД.

Розрахункову схему будемо розглядати як основу для розроблення математичної моделі ОД. Тому РС містить в собі всі основні функціональні аспекти ОД. В іншому випадку при створенні РС необхідно реалізовувати відповідні спрощення у структурі ОД зі схематизацією зв'язків між ії елементами.

Серед основних етапів розроблення $\mathrm{PC}$ виділимо наступні:

1. Конкретизація узагальненої геометричної моделі ОД.

2. Визначення набору параметрів відповідно заданої проблемної орієнтації з розділенням на вхідні та вихідні.

3. Ідеалізація та спрощення предметної області.

4. Схематичне представлення ОД. 
Розрахункова схема може бути представлена у графічноескізному виді з конкретним схематичним описанням зв'язків між її параметрами. У процесі реалізації вищезгаданих етапів необхідно забезпечити виконання наступних основних вимог до РС:

1. Можливість ефективного адекватного математичного описування ОД.

2. Наявність всіх основних конструктивно-технологічних параметрів, що описують поведінку об'єкту у реальних просторово-часових умовах.

3. Забезпечення можливості отримання результатів обчислень відповідно до мети досліджень та зручність їх інтерпретації.

Загальна методика розроблення математичної моделі складається з наступних етапів (рис. 4):

1. Формулювання математичних співвідношень, що з'єднують всі параметри, які представлені у РС ОД. Ці співвідношення повинні мати вигляд замкненої системи рівнянь, що описує поведінку ОД у реальних просторово-часових умовах.

2. Розв'язання співвідношень відносно вихідних параметрів та розроблення послідовності дій (алгоритму) з перетворення вхідних параметрів у вихідні.

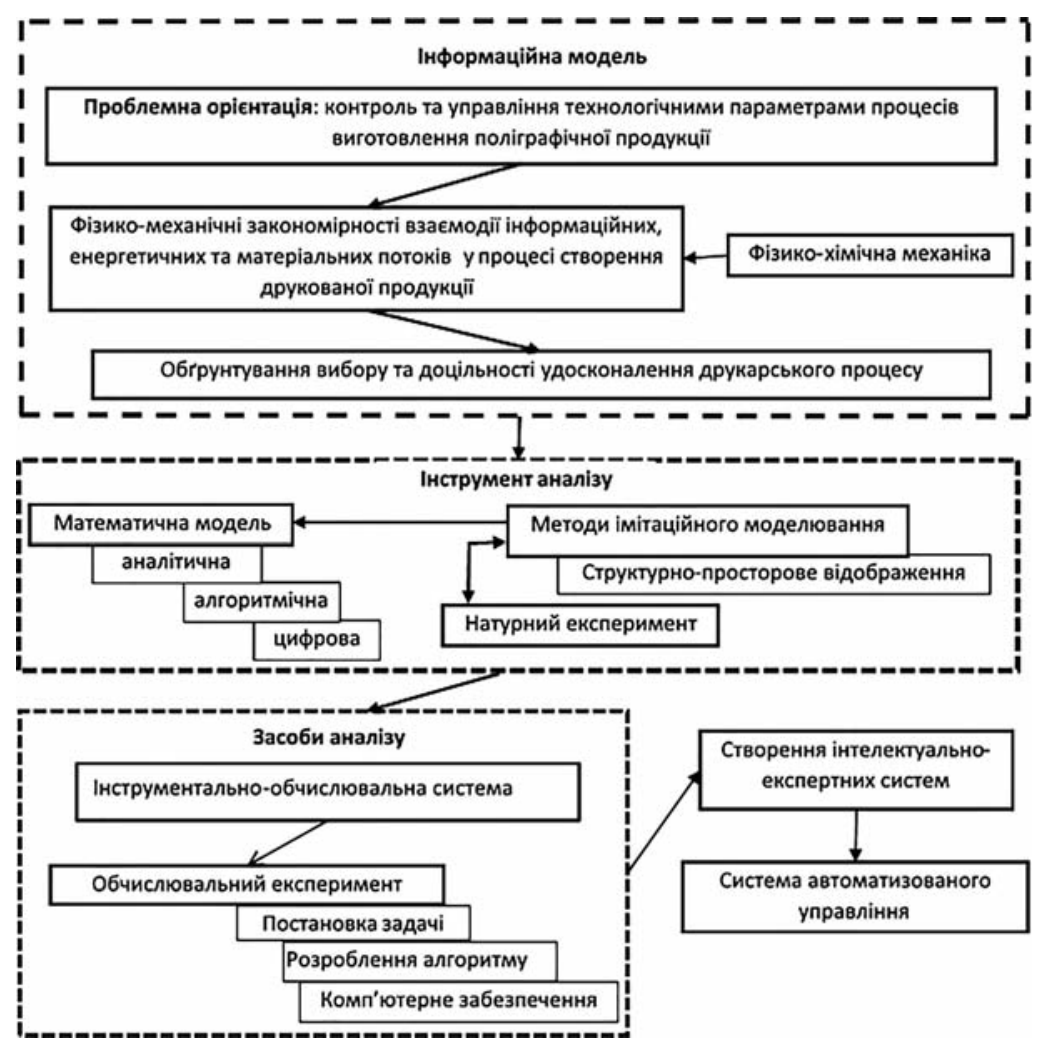

Рис. 2. Структура узагальненої інформаційної системи автоматизованого управління поліграфічними процесами 
3. Виконання реалізації розробленого алгоритму увиді комп'ютерної програми, яка забезпечить автоматизацію проведення досліджень.

Кожен з вищезгаданих етапів представляє собою окрему, інколи достатньо складну задачу. Результатом виконання кожного з даних трьох етапів будемо вважати створення трьох взаємозв'язаних моделей аналітичної, алгоритмічної та цифрової відповідно (рис. 4.). Для підвищення ефективності створення математичної моделі ОД пропонується використовувати CASE (Computer Aided Software Engineering) - технологію проектування IC, яка складається з набору методів, нотацій та інструментальних засобів, що дозволяють у наочній формі моделювати предметну область, аналі- зувати цифрову модель системи на всіх етапах розробки та супроводу і розробляти додатки відповідно до інформаційних потреб користувачів [12].

Запропонована методика дозволяє розробляти функціональне ядро - процесор при створенні IC аналізу, контролю та управління окремими технологічними операціями друку. Основні ії положення не суперечать методологічним підходам до створення програмно-технічного забезпечення, представленими в $[13,14]$, де для створення аналітичної моделі використано результати вимірювань технологічних параметрів на фізичних моделях 3 подальшим втіленням у цифровій моделі при розробленні відповідних засобів управління.

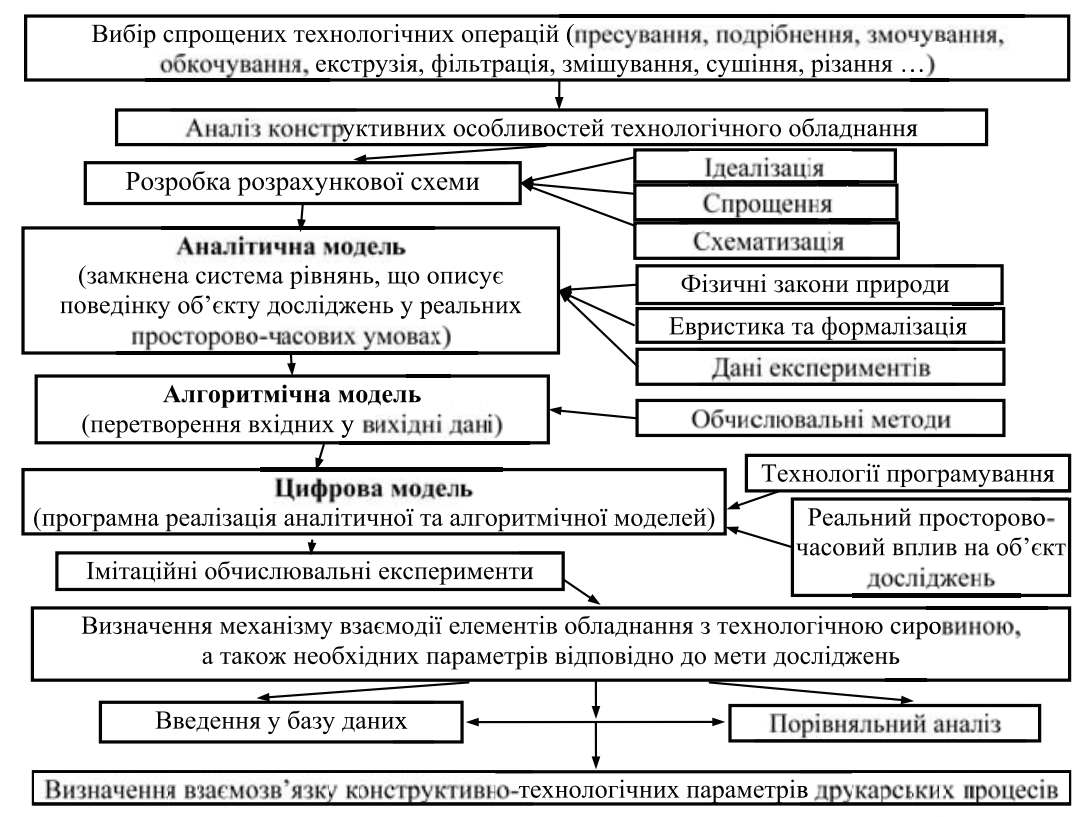

Рис. 3. Схема методики визначення взаємозв'язку конструктивнотехнологічних параметрів друкарських процесів 


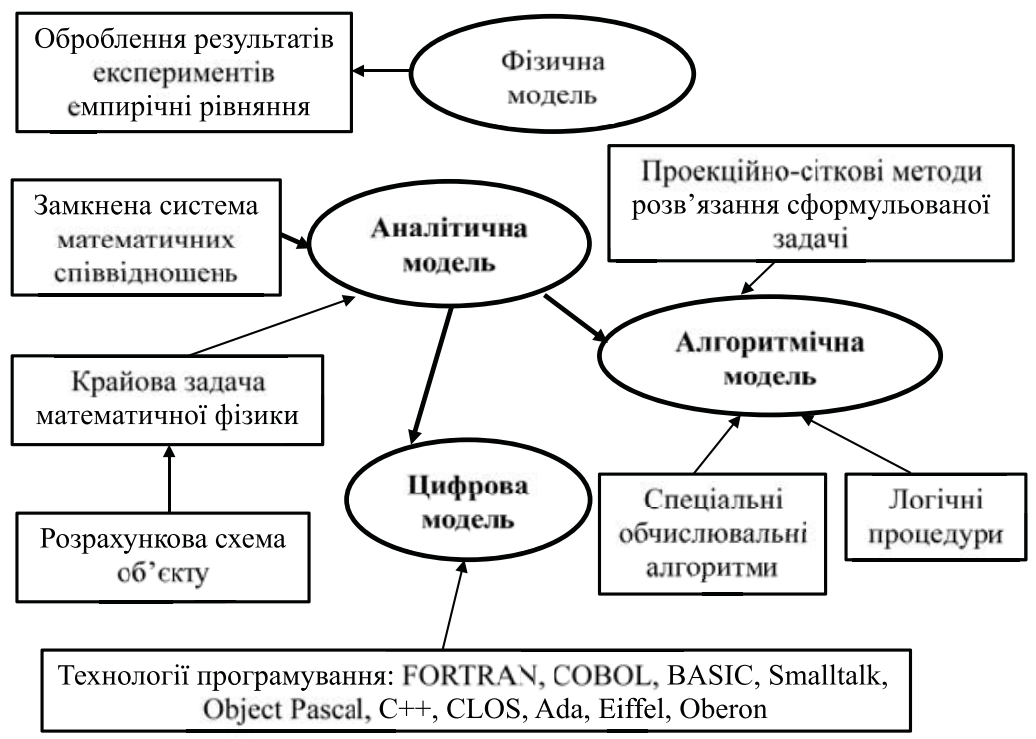

Рис. 4. Методика розроблення математичної моделі

\section{Висновки}

1. Проаналізовано особливості використання IC на сучасних поліграфічних підприємствах.

2. Обґрунтовано доцільність використання об'єктно-орієнтованих методів при створенні інформаційних проблемно-орієнтованих систем контролю та управління процесами відтворення відбитків.

3. Запропоновано тип IC контролю та управління процесом друку: «цифрова модель-інтелек- туальна експертна система-система автоматизованого управління».

4. Представлено принципи створення інформаційної та математичної моделей об'єкту досліджень у межах прийнятої проблемної орієнтації.

5. Намічено шляхи практичного використання запропонованих методологічних розробок при створенні інформаційних систем конкретних репрографічних технологій.

\section{Список використаної літератури}

1. Розум О. Ф. Таємниці друкарства: минуле, сучасне, майбутнє: навч. посіб. / О. Ф. Розум, О. М. Величко, О. М. Мельников // Вид. 2-е, перероб. і доп. Львів: Укр. акад. друкарства, 2012. 280 с.

2. Морфлюк В. Ф. Цифрове визначення та стабілізація параметрів технологічних процесів у рулонних друкарських машинах / В. Ф. Морфлюк. Київ: ВПЦ «Київська політехніка». 2008. 164 с.

3. Недашківський О. Л. Планування та проектування інформаційних систем / О. Л. Недашківський. К., 2014. 215 с.

4. Штефан $€$. В. Інформаційні технології проектування процесів та обладнання видавничо-поліграфічних виробництв / Є. В. Штефан // Сучасне репродукування: інжиніринг, моделювання, мульти- та кросмедійні техно- 
логії [Електронний ресурс]: матеріали наук.-практ. семінару кафедри репрографії КПІ ім. Ігоря Сікорського, 23 жовтня 2019 р. Електронні текстові дані. Київ: КПІ ім. Ігоря Сікорського, Вид-во «Політехніка», 2019. С. $125-130$.

5. Комп'ютеризовані системи і технології видавничо-поліграфічних виробництв: монографія / Під ред. О. І. Пушкаря. Харків: ІНЖЕК, 2011. 296 с.

6. Буч Г. Объектно-ориентированный анализ и проектирование / Г. Буч // 2-е изд.: пер. с англ. СПб.: Бином, 2000. 558 с.

7. Гетьман І. А. Технології проектування інформаційних систем / І. А. Гетьман, л. В. Васильєва // Computer Sciences and System Sciences (CS\&SS-2017). 2017. С. 76-79.

8. Гоменюк С. И. Объектно-ориентированные модели и методы анализа механических процессов / С. И. Гоменюк. Никополь: Никопольская комунальная типография, 2004. 316 с.

9. Величко О. М. Опрацювання інформаційного потоку взаємодією елементів друкарського контакту / О. М. Величко: Монографія. К.: Видавничополіграфічний центр «Київський університет», 2005. 264 с.

10. Морфлюк В. Ф. Проблемно-орієнтовані засоби керування технологічним процесом друку / В. Ф. Морфлюк // Комп'ютерні технології друкарства. 2002. № 8. С. 62-66.

11. Величко О. М. Інформаційний потік друкарської системи / О. М. Величко // Поліграфія і видавнича справа. Львів: УАД. 2001. Вип. 37. С. 87-95.

12. Савеленко О. К. CASE-технології у проектуванні інформаційних систем: навч. посіб. / О. К. Савеленко, І. А. Лисенко, О. О. Іванченко; Мін-во освіти і науки України, Центрально-україн. нац. техн. ун-т. Кропивницький: Лисенко В. Ф., 2018. 240 с.

13. Морфлюк В. Ф. Проблемно-орієнтовані засоби контролю та регулювання параметрів суміщення фарб / В. Ф. Морфлюк // Друкарство. 2005. № $1(60)$. C. 39-43.

14. Морфлюк В. Ф. Мультипрограмні засоби стабілізації параметрів технологічних процесів у рулонних друкарських машинах / В. Ф. Морфлюк // Друкарство. 2005. № 6(65). С. 44-46.

\section{References}

1. Rozum, O. F., Velychko, O. M., \& Melnykov, O. M. (2012). Taiemnytsi drukarstva: mynule, suchasne, maibutnie [Secrets of Printing: Past, Present, Future]. Lviv: Ukr. akad. drukarstva, 280 p. [in Ukrainian].

2. Morfliuk, V. F. (2008). Tsyfrove vyznachennia ta stabilizatsiia parametriv tekhnolohichnykh protsesiv u rulonnykh drukarskykh mashynakh [Digital Definition and Stabilization of Parameters of Technological Processes in Web Printing Machines]. Kyiv: VPTs 'Kyivska politekhnika', 164 p. [in Ukrainian].

3. Nedashkivskyi, O. L. (2014). Planuvannia ta proektuvannia informatsiinykh system [Planning and Design of Information Systems]. Kyiv, 215 p. [in Ukrainian].

4. Shtefan, Ye. V. (2019). Informatsiini tekhnolohii proektuvannia protsesiv ta obladnannia vydavnycho-polihrafichnykh vyrobnytstv [Information Technologies of Design Processes and Equipment of Publishing and Printing Industries]. Suchasne reprodukuvannia: inzhynirynh, modeliuvannia, multy- ta krosmediini tekhnolohii (23 October), 125-130 [in Ukrainian].

5. (2011). Komp'iuteryzovani systemy i tekhnolohii vydavnycho-polihrafichnykh vyrobnytstv [Computerized Systems and Technologies of Publishing and Printing Industries]. Kharkiv: INZhEK, 296 p. [in Ukrainian]. 
6. Buch, G. (2000). Ob'ektno-orientirovannyy analiz i proektirovanie [ObjectOriented Analysis and Design]. Sankt-Peterburg: Binom, 558 p. [in Russian].

7. Hetman, I. A., \& Vasylieva, L. V. (2017). Tekhnolohii proektuvannia informatsiinykh system [Technologies of Information Systems Design]. Computer Sciences and System Sciences (CS\&SS-2017), 76-79 [in Ukrainian].

8. Gomenyuk, S. I. (2004). Ob'ektno-orientirovannye modeli i metody analiza mekhanicheskikh protsessov [Object-Oriented Models and Methods of Analysis of Mechanical Processes]. Nikopol': Nikopol'skaya komunal'naya tipografiya, 316 p. [in Russian].

9. Velychko, O. M. (2005). Opratsiuvannia informatsiinoho potoku vzaiemodiieiu elementiv drukarskoho kontaktu [Processing of Information Flow by the Interaction of Elements of Printing Contact]. Kyiv: Vydavnycho-polihrafichnyi tsentr 'Kyivskyi universytet', 264 p. [in Ukrainian].

10. Morfliuk, V. F. (2002). Problemno-oriientovani zasoby keruvannia tekhnolohichnym protsesom druku [Problem-Oriented Means of Managing the Technological Process of Printing]. Komp'iuterni tekhnolohii drukarstva, 8, 62-66 [in Ukrainian].

11. Velychko, O. M. (2001). Informatsiinyi potik drukarskoi systemy [Information Flow of the Printing System]. Polihrafiia i vydavnycha sprava, 37, 87-95 [in Ukrainian].

12. Savelenko, O. K., Lysenko, I. A., \& Ivanchenko, O. O. (2018). CASE-tekhnolohii u proektuvanni informatsiinykh system [CASE-technologies in the design of information systems]. Kropyvnytskyi: Lysenko V. F., 240 p. [in Ukrainian].

13. Morfliuk, V. F. (2005). Problemno-oriientovani zasoby kontroliu ta rehuliuvannia parametriv sumishchennia farb [Problem-Oriented Means of Control and Regulation of Color Combination Parameters]. Drukarstvo, 1(60), 39-43 [in Ukrainian].

14. Morfliuk, V. F. (2005). Multyprohramni zasoby stabilizatsii parametriv tekhnolohichnykh protsesiv u rulonnykh drukarskykh mashynakh [Multiprogram Means of Stabilizing the Parameters of Technological Processes in Web Printing Machines]. Drukarstvo, 6(65), 44-46 [in Ukrainian].

The work is devoted to the methodological support problem of digital control and information management computer methods of technological processes for the production modes implementation in the logistics system 'layout-product'. The creation features of specialized information systems in the form of software and hardware for the technological factors management with their real dependence on input materials properties, condition, adjustment and mode of the equipment basic elements are considered.

Keywords: object-oriented methodology; information system; digital and mathematical models; intellectual expert system; problem-oriented means; printing production. 